\title{
Synthesis of Nickel(II) Complexes Using Malonodihydrazone Ligands Having Long Chain Pendent Arms
}

\author{
H. M. Tariqul Islam ${ }^{1}$, R. Shabnam² ${ }^{2}$ B. H. Howlader ${ }^{2}$, M. A. Latif ${ }^{1}$, B. M. Chaki ${ }^{1}$ \& M. A. Jalil Miah ${ }^{1}$ \\ ${ }^{1}$ Department of Chemistry, Begum Rokeya University, Rangpur \\ ${ }^{2}$ Department of Chemistry, University of Rajshahi, Rajshahi \\ Correspondence: H. M. Tariqul Islam, Department of Chemistry, Begum Rokeya University, Rangpur-5400, \\ Bangladesh. Tel: 88-174-005-4154.E-mail: hmtis09@yahoo.com
}

Received: June 16, 2012 Accepted: June 29, 2012 Online Published: September 18, 2012

doi:10.5539/ijc.v4n5p16 URL: http://dx.doi.org/10.5539/ijc.v4n5p16

\begin{abstract}
The Schiff base complexes of transition metals have been widely used in biological, industrial and analytical fields. The present work is synthesis and characterization of some complexes. The complexes $\mathrm{K}_{2}[\mathrm{Ni}(\mathrm{C}$ $\left.\left.{ }_{31} \mathrm{H}_{26} \mathrm{~N}_{4} \mathrm{O}_{4}\right)_{2}\right], \mathrm{K}_{2}\left[\mathrm{Ni}\left(\mathrm{C}_{29} \mathrm{H}_{38} \mathrm{~N}_{4} \mathrm{O}_{4}\right)_{2}\right]$, and $\mathrm{K}_{2}\left[\mathrm{Ni}\left(\mathrm{C}_{41} \mathrm{H}_{62} \mathrm{~N}_{4} \mathrm{O}_{2}\right)_{4}\right]$, have been prepared by the reaction of Schiff bases with nickel(II) acetate tetrahydrate in the presence of base $(\mathrm{KOH})$ in 2:1 molar ratio. The Schiff base ligands e.g. $\mathrm{L}^{\prime} \mathrm{H}_{2}, \quad \mathrm{~L}^{\prime \prime} \mathrm{H}_{2}$ and $\mathrm{L}^{\prime \prime \prime} \mathrm{H}_{2}$ were prepared from the reaction of malonodihydrazide with 4-benzyloxybenzaldehyde, 4-hexyloxybenzaldehyde and 4-dodecyloxybenzaldehyde.

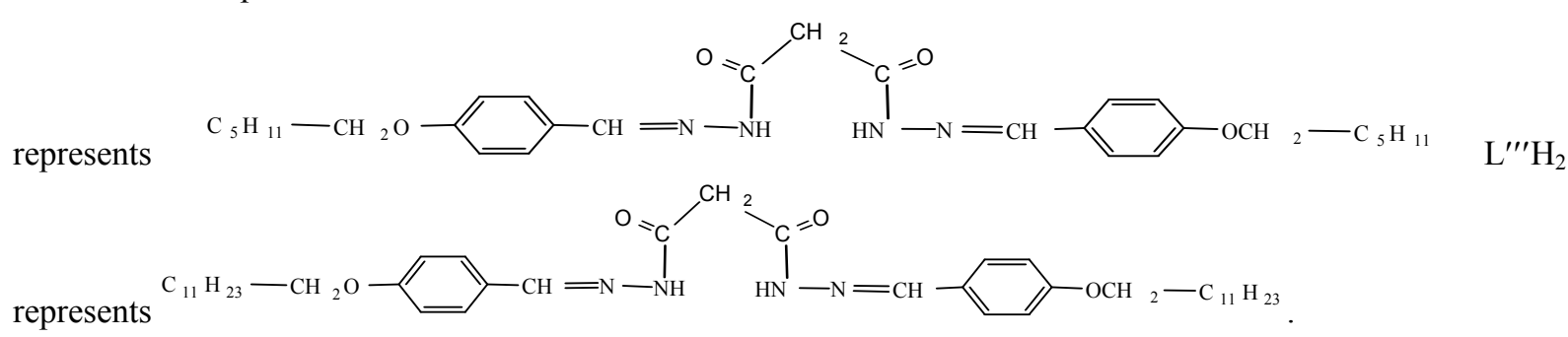

The complexes 1-3 have been characterized on the basis of elemental analysis, metal estimation, magnetic moments, conductance measurements, IR and UV-visible spectra and study of other physical properties. The suggested structures of the complexes 1-3 are square planar in nature.

Keywords: Schiff base complex, Schiff base ligand, malonodihydrazide, 4-benzyloxybenzaldehyde, 4-hexyloxybenzaldehyde, 4-dodecyloxybenzaldehyde

\section{Introduction}

Coordination chemistry at present stands as a land mark in the field of scientific advancement, embracing most diverse branches of science, engineering and technology. A complex has been defined as a species formed by the association of two or more simpler species capable of independent existence. (Rossotti et al., 1961). Although Jorgensen (1837-1914) started the extensive studies on the synthesis of complex compounds, it was not until 1906 when the recognition of the true nature of complexes began with Alfred Werner (1866-1919) as set out in his classic work Neuere Anschauungen ouf dem Gebiete der anorganischen chemie (Werner, 1911). For this pioneering work, Alfred Werner received the Nobel Prize in 1913. In fact he was the founder of modern coordination chemistry who postulated the first successful theory known as "Werner's coordination theory" to explain the formation, properties and stereochemistry of coordination compounds. The independent approaches of Sidgwick (1923) and Lowry (1923) are that a chemical bond required the sharing of an electron molecule with an electron pair. This led to the idea that a neutral molecule with an electron pair (Lewis base) can donate these electrons to a metal ion or other electron acceptor (Lewis acid). 
Although the electron pair donor-acceptor concept of Lewis (Basdo et al., 1964) is still useful for many Lewis-acid base interactions for complex formation, it is apparent that the understanding towards the nature of bonding in metal complexes requires more detailed considerations. At the present time, four more or less distinct approaches to the theoretical treatment of the bonding and properties of coordination compounds are recognized. These theories are the Valence Bond Theory (VBT) (Bethe, 1929; Pouling, 1960), the Crystal Field Theory (CFT) (Pauling, 1960; Orgel, 1960), the Ligand Field Theory (LFT) (Figgis, 1960; Vanvleck, 1935), and the Molecular Orbital Theory (MOT) (Vanvleck, 1985; Graw, 1964).

Every Lewis acid-base reaction involving essentially the formation of coordinate covalent bond can be called a complex formation reaction. The chemistry of Schiff base complexes have attracted a great deal of attention ever since Pfeiffer carried out his Pioneer research in the 1930's. The reactivity of coordination compounds is dramatically changed on the basis of complexation. Some important interesting reactions of substituted bis-salicylaldimine chelates of copper and nickel in which the organic groups attached to nitrogen of the donors are altered have been reported.The importance and application of metal complexes in analytical Chemistry are well known (Gruses et al., 1983). The Schiff base ligands play an important role in some biological systems and their function is related, at least in part, to its chelating ability with metal. In the recent years, a considerable attention has been given to synthesis of some Schiff base complexes to study their biological activity. Therefore, the interest of the present work is to synthesis and characterization of some Schiff base complexes.

\section{Experimental}

Preparations of 4-alkyl/aryloxybenzaldehyde (1) were done by reflux of 4-hydroxybenzaldehyde, alkyl/arylbromide and anhydrous $\mathrm{K}_{2} \mathrm{CO}_{3}$ in acetone. Malonodihydrazide $\mathrm{C}_{3} \mathrm{H}_{8} \mathrm{~N}_{4} \mathrm{O}_{2}$ (2) was prepared by the reaction of Diethylmalonate and hydrazine hydrate. To the aqueous solution of malonodihydrazide, $\mathrm{C}_{3} \mathrm{H}_{8} \mathrm{~N}_{4} \mathrm{O}_{2}$, 4-alkyl/aryloxy-benzaldehyde solutions were added. Preparations of Schiff base ligands $\mathrm{L}^{\prime} \mathrm{H}_{2}, \mathrm{C}_{31} \mathrm{H}_{28} \mathrm{~N}_{4} \mathrm{O}_{4}, \mathrm{~L}^{\prime \prime} \mathrm{H}_{2}$, $\mathrm{C}_{29} \mathrm{H}_{40} \mathrm{~N}_{4} \mathrm{O}_{4}$ and L'" $\mathrm{H}_{2}, \mathrm{C}_{41} \mathrm{H}_{64} \mathrm{~N}_{4} \mathrm{O}_{4}$ (3) were completed as white powdered products. To the ethanolic solution of the ligands the nickel (II) acetate tetrahydrate solution was added and then the ethanolic solution of potassium hydroxide was added. Finally, the complexes $\mathrm{K}_{2}\left[\mathrm{Ni}\left(\mathrm{C}_{31} \mathrm{H}_{26} \mathrm{~N}_{4} \mathrm{O}_{4}\right)_{2}\right], \quad \mathrm{K}_{2} \quad\left[\mathrm{Ni} \quad\left(\mathrm{C}_{29} \mathrm{H}_{38} \mathrm{~N}_{4} \mathrm{O}_{4}\right)_{2}\right]$, and $\mathrm{K}_{2}\left[\mathrm{Ni}\left(\mathrm{C}_{41} \mathrm{H}_{62} \mathrm{~N}_{4} \mathrm{O}_{4}\right)_{2}\right]$ (4) are synthesised as yelloish amorphous solids.

The synthetic route of the complexes is shown in the following scheme:

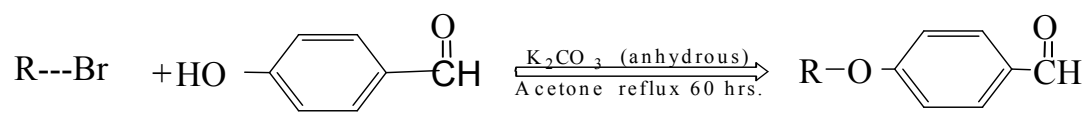

(1)

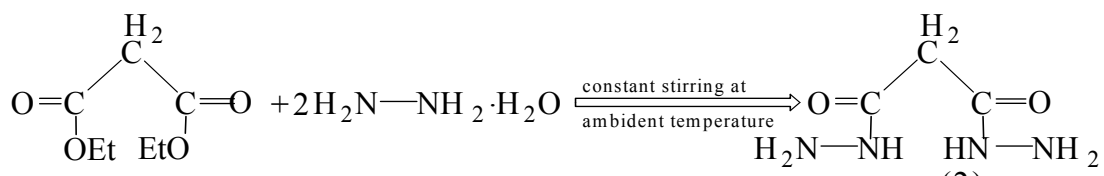

(2)

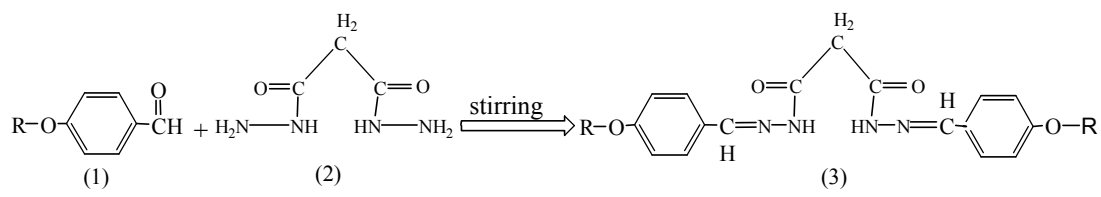




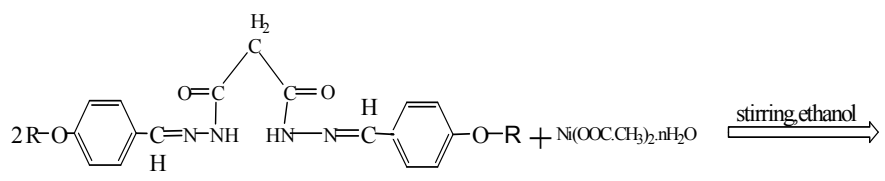

(3)

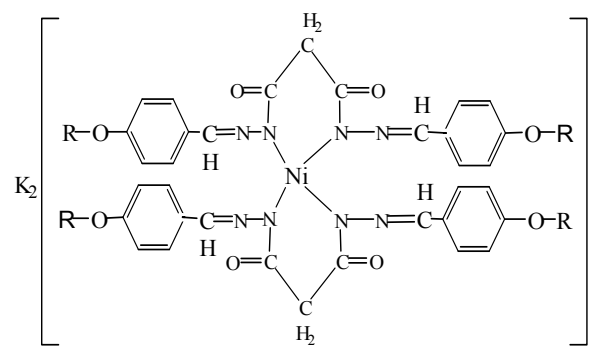

(4)

Where, $\mathrm{R} \equiv \mathrm{C}_{6} \mathrm{H}_{5}-\mathrm{CH}_{2^{-}}, \mathrm{C}_{6} \mathrm{H}_{13^{-}}, \mathrm{C}_{12} \mathrm{H}_{25^{-}}$.

The characterizations of each products are done through weighing, elemental analysis, metal estimation, infrared spectra and uv-visible spectra study; conductivity, magnetic moments and melting point measurements and thin layer chromatography (TLC).

\section{Results and Discussion}

\subsection{Synthesis of 4-benzyloxybenzaldehyde}

The compound (5) was synthesized by the reaction of 4-hydroxybenzaldehyde with benzylbromide in the presence of anhydrous potassium carbonate. The infrared spectrum $f$ the compound (5) showed a strong absorption band at $1686 \mathrm{~cm}^{-1}$ which is suggested for stretching frequency of $v(C=O)$ of aldehyde group. The band at $1601,1576 \mathrm{~cm}^{-1}$ are suggested for the aromatic, $v(\mathrm{C}=\mathrm{C})$ stretching frequencies. The bands at 1111 and $1167 \mathrm{~cm}^{-1}$ may be assigned to the $v(\mathrm{C}-\mathrm{O})$ absorption. The absence of hydroxyl band at $3400-3600 \mathrm{~cm}^{-1}$ region indicated the formation of compound (5).

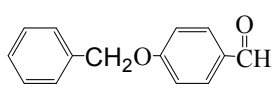

(5)

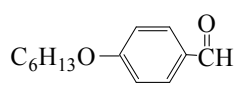

(6)

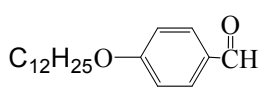

(7)

Therefore, the elemental analysis and IR spectral data suggested that the compound is the expected aldehyde, 4-benzyloxybenzaldehyde (5).

\subsection{Synthesis of 4-Hexyloxybenzaldehyde}

The compound (6) was synthesized by the reaction of 4-hydroxy benzaldehyde with hexylbromide in the present of anhydrous potassium carbonate. The infrared spectrum of the compound (6) showed a strong absorption band at $1686 \mathrm{~cm}^{-1}$ which is suggested for stretching frequency of $v(\mathrm{C}=\mathrm{O})$ of aldehyde group. The band at 1601, 1576 $\mathrm{cm}^{-1}$ are suggested for the aromatic, $v(\mathrm{C}=\mathrm{C})$ stretching frequencies. The bands at 1111 and $1167 \mathrm{~cm}^{-1}$ may be assigned to the $v(\mathrm{C}-\mathrm{O})$ absorption. The absence of hydroxyl band at $3400-3600 \mathrm{~cm}^{-1}$ region indicated the formation of compound (6). Therefore, the elemental analysis and IR spectral data suggested that the compound is the expected aldehyde, 4-hexyloxybenzaldehyde (6).

\subsection{Synthesis of 4-dodecyloxybenzaldehyde}

The compound (7) was synthesized by the reaction of 4-hydroxy benzaldehyde with benzylbromide in the presence of anhydrous potassium carbonate. The infrared spectrum (Figure 3) of the compound (7) showed a strong absorption band at $1686 \mathrm{~cm}^{-1}$ which is suggested for stretching frequency of $v(\mathrm{C}=\mathrm{O})$ of aldehyde group. The band at $1601,1576 \mathrm{~cm}^{-1}$ are suggested for the aromatic, $v(\mathrm{C}=\mathrm{C})$ stretching frequencies. The bands at 1111 and $1167 \mathrm{~cm}^{-1}$ may be assigned to the $v(\mathrm{C}-\mathrm{O})$ absorption. The absence of hydroxyl band at $3400-3600 \mathrm{~cm}^{-1}$ region indicated the formation of compound (7). Therefore, the elemental analysis and IR spectral data suggested that the compound is the expected aldehyde, 4-dodecyloxybenzaldehyde (7). 
Table 1. Elemental analysis and other physical properties of compounds 5, 6 and 7

\begin{tabular}{ccccccccc}
\hline $\begin{array}{c}\text { Synthesize } \\
\text { compounds(5-7) } \\
\text { and their physical } \\
\text { state }\end{array}$ & $\begin{array}{c}\text { Melting } \\
\text { point, }{ }^{\circ} \mathrm{C}\end{array}$ & & \multicolumn{2}{c}{$\% \mathrm{C}$} & \multicolumn{2}{c}{$\% \mathrm{H}$} & \multicolumn{2}{c}{$\% \mathrm{O}$} \\
\cline { 3 - 8 } & & Calculated & Found & Calculated & Found & Calculated & Found \\
\hline $\begin{array}{c}\text { 5. }\left(\mathrm{C}_{14} \mathrm{H}_{12} \mathrm{O}_{2}\right), \\
\quad \begin{array}{l}\text { Yellowish } \\
\text { powdered }\end{array}\end{array}$ & 72 & 79.25 & 78.80 & 5.09 & 5.01 & 15.09 & 14.48 \\
$\begin{array}{c}\text { 6. }\left(\mathrm{C}_{13} \mathrm{H}_{18} \mathrm{O}_{2}\right), \\
\text { Yellowish liquid }\end{array}$ & - & 75.73 & 74.89 & 8.74 & 8.41 & 15.53 & 15.09 \\
$\begin{array}{c}\text { 7. }\left(\mathrm{C}_{19} \mathrm{H}_{30} \mathrm{O}_{2}\right), \\
\text { Reddish brown } \\
\text { liquid }\end{array}$ & - & 78.62 & 78.20 & 10.34 & 9.39 & 11.04 & 10.65 \\
\hline
\end{tabular}

Table 2. Important infrared spectral bands of compounds (5,6 and 7)

\begin{tabular}{cccc}
\hline Compounds & $v(\mathrm{C}=\mathrm{O})$ aldehyde $\left(\mathrm{cm}^{-1}\right)$ & $v(\mathrm{C}=\mathrm{C})$ aromatic $\left(\mathrm{cm}^{-1}\right)$ & $v(\mathrm{C}-\mathrm{O}) \mathrm{cm}^{-1}$ \\
\hline 5. $\left(\mathrm{C}_{14} \mathrm{H}_{12} \mathrm{O}_{2}\right)$ & 1686 & 1601,1576 & 1111,1167 \\
6. $\left(\mathrm{C}_{13} \mathrm{H}_{18} \mathrm{O}_{2}\right)$ & 1686 & 1601,1576 & 1111,1167 \\
7. $\left(\mathrm{C}_{19} \mathrm{H}_{30} \mathrm{O}_{2}\right)$ & 1686 & 1601,1576 & 1111,1167 \\
\hline
\end{tabular}

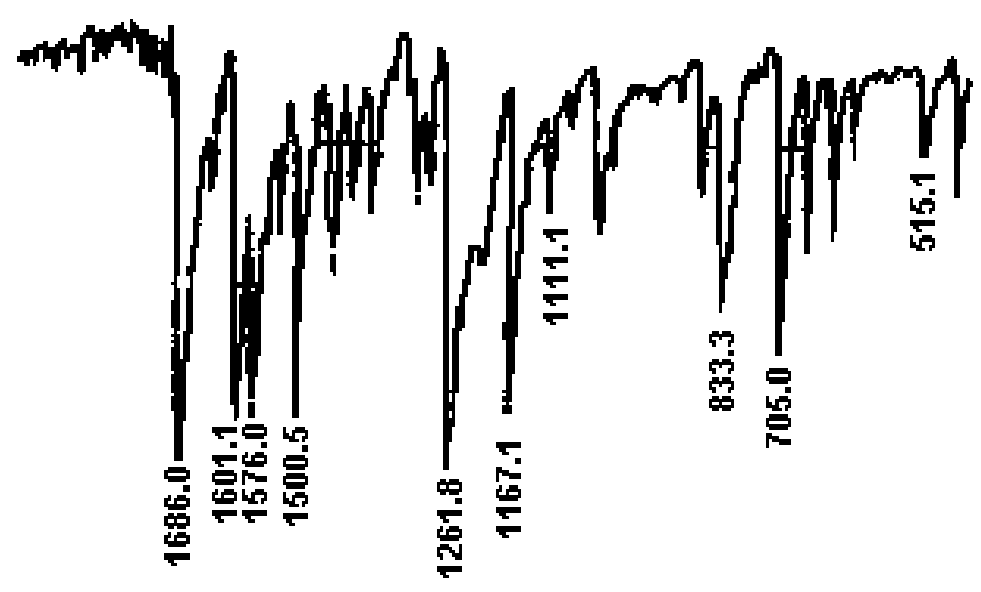

Figure 1. Infrared spectrum of compound (5), $\mathrm{C}_{14} \mathrm{H}_{12} \mathrm{O}_{2}$ 


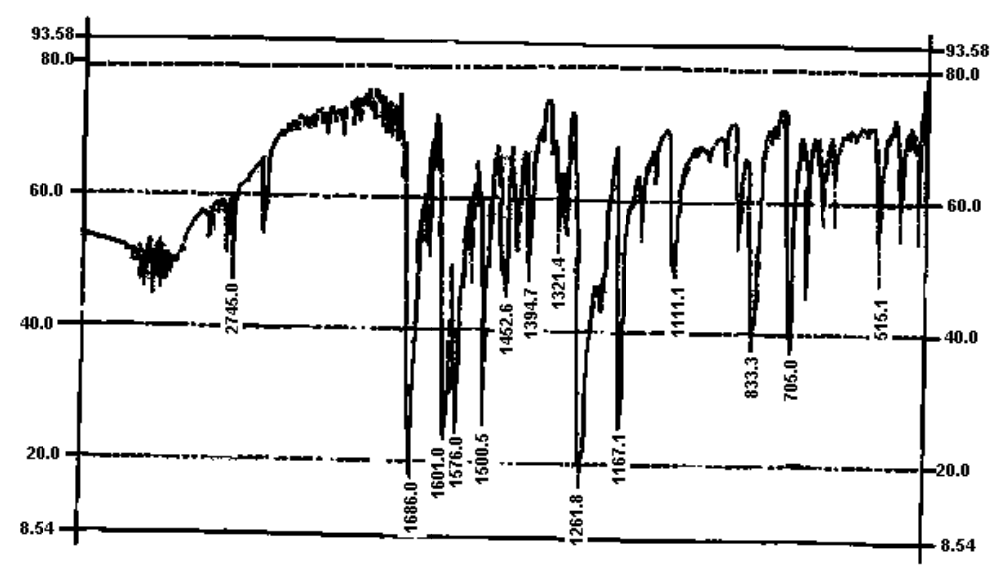

Figure 2. Infrared spectrum of compound (6), $\mathrm{C}_{13} \mathrm{H}_{18} \mathrm{O}_{2}$

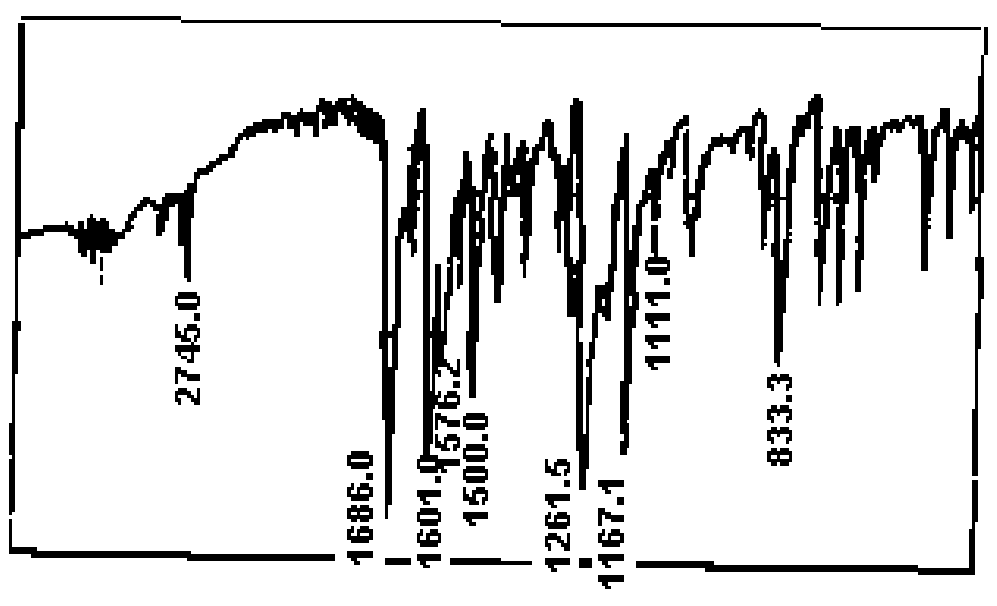

Figure 3. Infrared spectrum of compound (7), $\mathrm{C}_{19} \mathrm{H}_{30} \mathrm{O}_{2}$

\subsection{Synthesis of the Schiff Bases}

The Schiff base ligands (e.g. $\mathrm{L}^{\prime} \mathrm{H}_{2}, \mathrm{~L}^{\prime \prime} \mathrm{H}_{2}$ and $\mathrm{L}^{\prime \prime \prime} \mathrm{H}_{2}$ ) were prepared by the reaction of malonodihydrazide with 4-benzyloxybenzaldehyde, 4-hexyloxy benzaldehyde and 4-dodecyloxybenzaldehyde respectively at ambient temperature. The ligands have been characterized by IR spectra, elemental analysis and other physical properties. The infrared spectra of the ligands $\left(\mathrm{L}^{\prime} \mathrm{H}_{2}, \mathrm{~L}^{\prime \prime} \mathrm{H}_{2}\right.$ and $\left.\mathrm{L}^{\prime \prime \prime} \mathrm{H}_{2}\right)$ are shown in Figure $(1,2$ and 3$)$ respectively. The spectral data (Table 4) of the ligands showed a strong band at (3213-3220) $\mathrm{cm}^{-1}$ region suggested for the $\mathrm{v}(\mathrm{N}-\mathrm{H})$ stretching of amide (-CONH-) group. [The starting material malonodihydrazide ${ }^{22}$ have three $v(\mathrm{~N}-\mathrm{H})$ bands at $(3248,3213,3050) \mathrm{cm}^{-1}$. The bands at $3248,3050 \mathrm{~cm}^{-1}$ for the asymmetric and symmetric $v(\mathrm{~N}-\mathrm{H})$ stretching of the terminal $\mathrm{NH}_{2}$ moiety and $3213 \mathrm{~cm}^{-1}$ for amide (-CONH-) group]. The ligands showed an absorption band at (1610-1624) $\mathrm{cm}^{-1}$ region suggested for the $v(\mathrm{C}=\mathrm{N})$ stretching. This indicated the condensation between aldehyde and terminal $\mathrm{NH}_{2}$ group of malonodihydrazide. The ligands showed a strong band at (1654-1670) $\mathrm{cm}^{-1}$ for $v(\mathrm{C}=\mathrm{O})$ stretching $^{24}$. A broad band at $(1577-1581) \mathrm{cm}^{-1}$ is due to the $v(\mathrm{C}=\mathrm{C})$ stretching of aromatic $\mathrm{C}=\mathrm{C}$ double bond.

The elemental analysis data and other physical properties (Table 3) of the ligands are consistent with their proposed formula. 
On the basis of infrared spectra, elemental analysis and other physical properties the suggested structure of the ligands $\left(\mathrm{L}^{\prime} \mathrm{H}_{2}, \mathrm{~L}^{\prime \prime} \mathrm{H}_{2}\right.$ and $\left.\mathrm{L}^{\prime \prime \prime} \mathrm{H}_{2}\right)$ are shown as:<smiles>O=C(CC(=O)NNCc1ccc(Cc2ccccc2)cc1)NN=C=Cc1ccc(Oc2ccccc2)cc1</smiles>

Bis[N-benzylidene(4-benzyloxy)]malonodihydrazone $\left(\mathrm{C}_{31} \mathrm{H}_{28} \mathrm{~N}_{4} \mathrm{O}_{4}\right)$ represents as $\mathrm{L}^{\prime} \mathrm{H}_{2}$ ligand

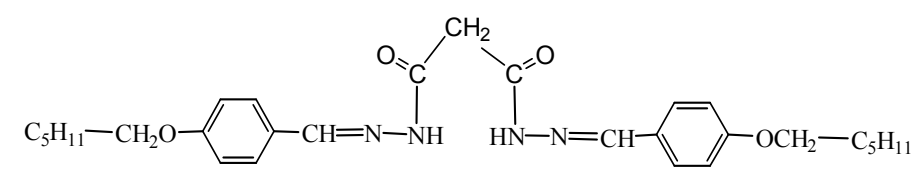

Bis[N-benzylidene(4-hexyloxy)] malonodihydrazone $\left(\mathrm{C}_{29} \mathrm{H}_{40} \mathrm{~N}_{4} \mathrm{O}_{4}\right)$ represents as $\mathrm{L}^{\prime \prime} \mathrm{H}_{2}$ ligand

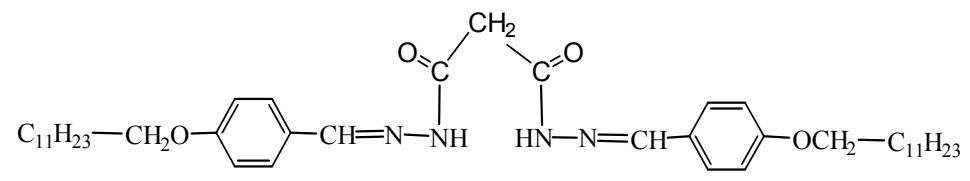

Bis[N-benzylidene(4-dodecyloxy)]malonodihydrazone $\left(\mathrm{C}_{41} \mathrm{H}_{64} \mathrm{~N}_{4} \mathrm{O}_{4}\right)$ represents as L"'H2 ligand

Table 3. Elemental analysis and other physical properties of Ligands $\left(\mathrm{L}^{\prime} \mathrm{H}_{2}, \mathrm{~L}^{\prime \prime} \mathrm{H}_{2}\right.$ and $\left.\mathrm{L}^{\prime \prime \prime} \mathrm{H}_{2}\right)$

\begin{tabular}{|c|c|c|c|c|c|c|c|c|c|}
\hline \multirow{2}{*}{$\begin{array}{l}\text { Ligands and physical } \\
\text { state }\end{array}$} & \multirow{2}{*}{$\begin{array}{c}\text { Melti } \\
\text { ng } \\
\text { point, } \\
{ }^{\circ} \mathrm{C}\end{array}$} & \multicolumn{2}{|c|}{$\% \mathrm{C}$} & \multicolumn{2}{|c|}{$\% \mathrm{H}$} & \multicolumn{2}{|c|}{$\% \mathrm{~N}$} & \multicolumn{2}{|c|}{$\% \mathrm{O}$} \\
\hline & & Calculated & Found & Calculated & Found & Calculated & Found & Calculated & Found \\
\hline $\begin{array}{c}\mathrm{L}^{\prime} \mathrm{H}_{2}\left(\mathrm{C}_{31} \mathrm{H}_{28} \mathrm{~N}_{4} \mathrm{O}_{4}\right) \\
\text { White Powdered }\end{array}$ & 196 & 71.51 & 55.80 & 5.43 & 6.71 & 10.76 & 23.65 & 12.30 & 13.48 \\
\hline $\begin{array}{c}\mathrm{L}^{\prime \prime} \mathrm{H}_{2}\left(\mathrm{C}_{29} \mathrm{H}_{40} \mathrm{~N}_{4} \mathrm{O}_{4}\right) \\
\text { White Powdered }\end{array}$ & 182 & 68.46 & 69.89 & $7 . .93$ & 5.41 & 11.02 & 15.45 & 12.59 & 8.79 \\
\hline $\begin{array}{c}\mathrm{L}^{\prime \prime \prime} \mathrm{H}_{2}\left(\mathrm{C}_{41} \mathrm{H}_{64} \mathrm{~N}_{4} \mathrm{O}_{4}\right), \\
\text { White Starfish like } \\
\text { crystal }\end{array}$ & 190 & 72.73 & 51.20 & 9.53 & 8.39 & 8.28 & 23.21 & 9.46 & 13.25 \\
\hline
\end{tabular}

Table 4. Important infrared spectral bands of ligands $\left(\mathrm{L}^{\prime} \mathrm{H}_{2}, \mathrm{~L}^{\prime \prime} \mathrm{H}_{2}\right.$ and $\left.\mathrm{L}^{\prime \prime \prime} \mathrm{H}_{2}\right)$

\begin{tabular}{cccccc}
\hline Ligands & $\begin{array}{c}v(\mathrm{~N}-\mathrm{H}) \\
\mathrm{cm}^{-1}\end{array}$ & $\begin{array}{c}v(\mathrm{C}-\mathrm{H}) \\
\mathrm{cm}^{-1}\end{array}$ & $v(\mathrm{C}=\mathrm{O}) \mathrm{cm}^{-1}$ & $v(\mathrm{C}=\mathrm{N}) \mathrm{cm}^{-1}$ & $v(\mathrm{C}=\mathrm{C}) \mathrm{cm}^{-1}$ \\
\hline $\mathrm{L}^{\prime} \mathrm{H}_{2}\left(\mathrm{C}_{31} \mathrm{H}_{28} \mathrm{~N}_{4} \mathrm{O}_{4}\right)$ & 3216 & 2931 & 1660 & 1614 & 1577 \\
$\mathrm{~L}^{\prime \prime} \mathrm{H}_{2}\left(\mathrm{C}_{29} \mathrm{H}_{40} \mathrm{~N}_{4} \mathrm{O}_{4}\right)$ & 3220 & 2920 & 1670 & 1624 & 1581 \\
$\mathrm{~L}^{\prime \prime \prime} \mathrm{H}_{2}\left(\mathrm{C}_{41} \mathrm{H}_{64} \mathrm{~N}_{4} \mathrm{O}_{4}\right)$ & 3213 & 2931 & 1654 & 1610 & 1575 \\
\hline
\end{tabular}




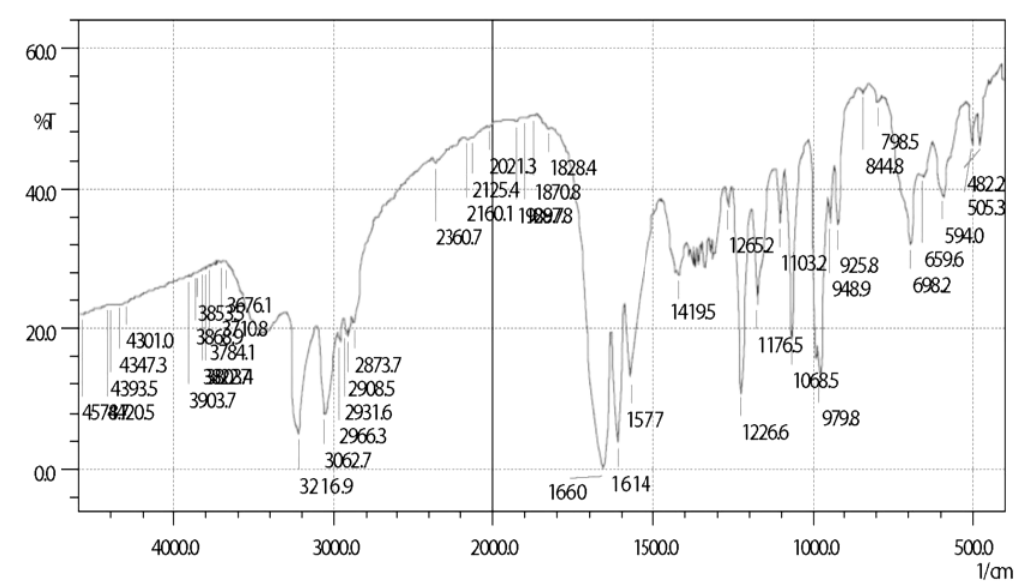

Figure 4. Infrared spectrum of $\mathrm{L}^{\prime} \mathrm{H}_{2}$ Schiff base

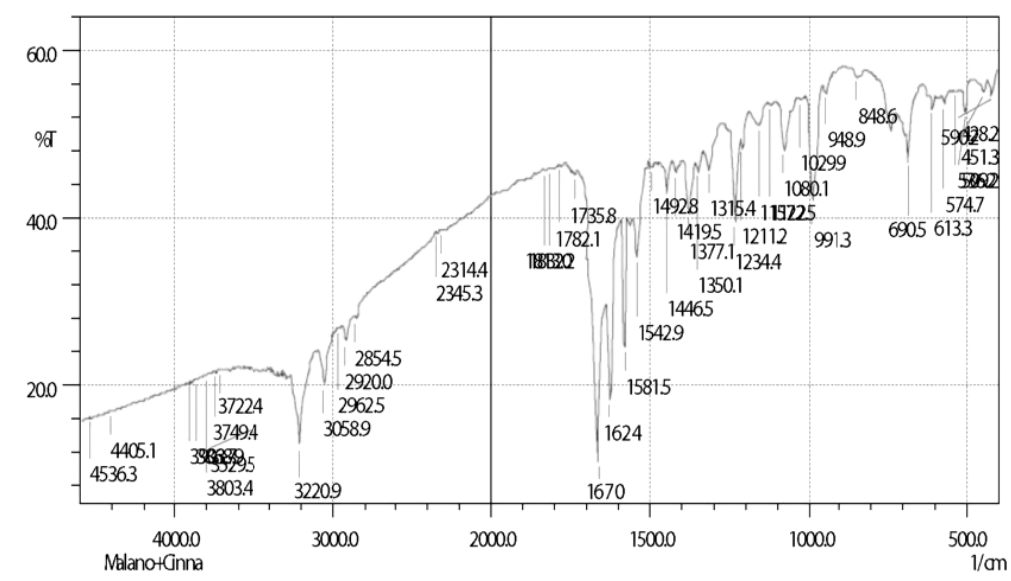

Figure 5. Infrared spectrum of $\mathrm{L}^{\prime \prime} \mathrm{H}_{2}$ Schiff base

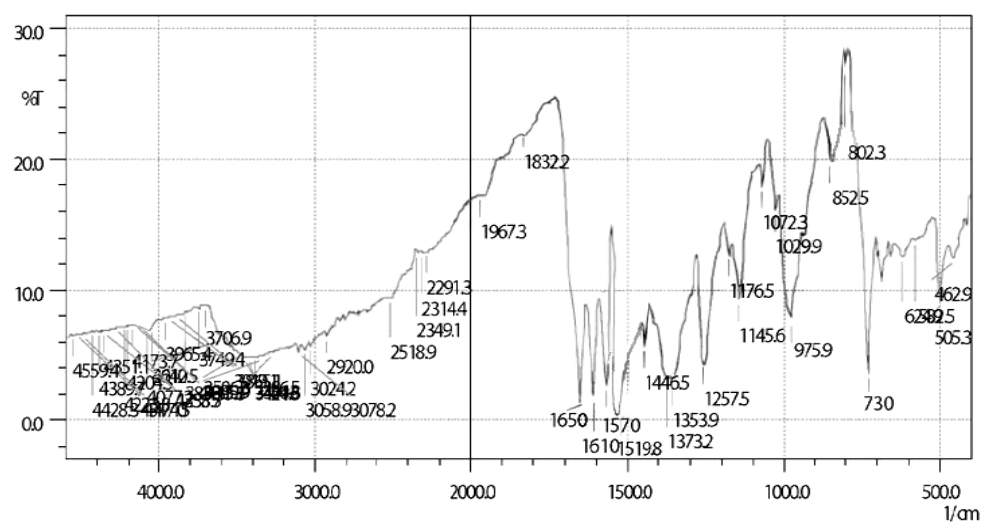

Figure 6. Infrared spectrum of $\mathrm{L}^{\prime \prime \prime} \mathrm{H}_{2}$ Schiff base ligand 
3.5 Reactions of Schiff Bases (e.g. $\mathrm{L}^{\prime} \mathrm{H}_{2}=\mathrm{C}_{31} \mathrm{H}_{28} \mathrm{~N}_{4} \mathrm{O}_{4}, \mathrm{~L}^{\prime \prime} \mathrm{H}_{2}=\mathrm{C}_{29} \mathrm{H}_{40} \mathrm{~N}_{4} \mathrm{O}_{4}$ and $\mathrm{L}^{\prime \prime} \mathrm{H}_{2}=\mathrm{C}_{41} \mathrm{H}_{64} \mathrm{~N}_{4} \mathrm{O}_{4}$ ) with Nickel(Ii) Acetatetetrahydrate in the Presence of Base (KOH): Synthesis of Complexes 1-3

The complexes 1-3 were prepared by the reaction of Schiff bases (e.g. $\mathrm{L}^{\prime} \mathrm{H}_{2}, \mathrm{~L}^{\prime \prime} \mathrm{H}_{2}$ and $\mathrm{L}^{\prime \prime \prime} \mathrm{H}_{2}$ ) with nickel(II) acetatetetrahydrate in the presence potassium hydroxide. The complexes have been characterized by elemental analysis, metal estimation, magnetic moments and conductance measurements, IR and UV-visible spectra and study of other Physical properties. The elemental analysis (Table 6) and metal estimation (Table 5) of the complexes 1-3 are consistent with the proposed formula. The conductance values (Table 5) of the complexes 1-3 reveal that they are 2:1 electrolytic in nature.

The infrared spectra (Figure 7, 8 and 9) of the complexes 1-3 showed (Table 7) absorption band at (1610-1620) $\mathrm{cm}^{-1}$ region suggested for $\mathrm{v}(\mathrm{C}=\mathrm{N})$ stretching. There is no band at $(3100-3300) \mathrm{cm}^{-1}$ region indicated the absence of $(\mathrm{N}-\mathrm{H})$ group of the complexes. This also indicated the deprotonation of amide (-CONH-) proton. The complexes showed a strong band at $(1650-1666) \mathrm{cm}^{-1}$ which represents the $v(\mathrm{C}=\mathrm{O})$ stretching. ${ }^{24} \mathrm{~A}$ broad band at $(1570-1580) \mathrm{cm}^{-1}$ is due to the $v(\mathrm{C}=\mathrm{C})$ double bond. A new band arises at $(730-748) \mathrm{cm}^{-1}$ is due to the $v(\mathrm{M}-\mathrm{N})$ stretching ${ }^{26}$, which indicates the coordination of ligand to the metal through the nitrogen atom.

The magnetic moment data of the complexes 1-3 are shown in Table 7. The magnetic moment of the complexes 1-3 showed negative value. These values corresponds that $\mathrm{Ni}(\mathrm{II}) \mathrm{d}^{8}$-system has no unpaired electron, suggested the diamagnetic complexes.

The UV-visible spectra of the complexes 1-3 are shown in Figure (10, 11 and 12). The complexes showed (Table 10) a single broad band at $400 \mathrm{~nm} \mathrm{1}$, at $430 \mathrm{~nm} \mathrm{2}$, and at $420 \mathrm{~nm} \mathrm{3}$, represent the d-d transition of ${ }^{1} \mathrm{~A}_{1 \mathrm{~g}} \rightarrow{ }^{1} \mathrm{~B}_{1 \mathrm{~g}}$ which suggested the square planar geometry of the $\mathrm{Ni}(\mathrm{II})$ complexes. The band observed below $400 \mathrm{~nm}$ assigned due to the $\pi \rightarrow \pi^{*}$ transition of the ligands.

On the basis of elemental analysis, magnetic moment, conductance measurements, metal estimation, IR and UV-visible spectra and other physical properties the suggested structure of complexes 1-3 are square planar in nature as shown in Figure (A), (B) and (C) respectively.

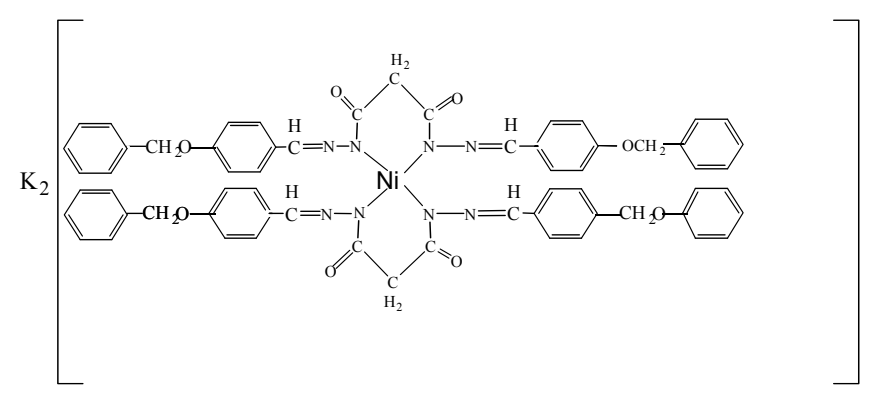

Figure (A). Square planar structure of $\mathrm{K}_{2}\left[\mathrm{Ni}\left(\mathrm{L}^{\prime}\right)_{2}\right]$ for complex 1, L' represents $\mathrm{C}_{31} \mathrm{H}_{26} \mathrm{~N}_{4} \mathrm{O}_{4}$

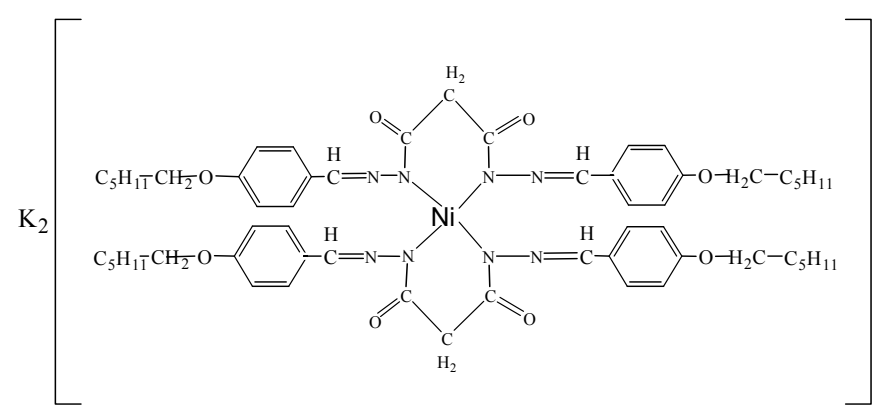

Figure (B). Square planar structure of $\mathrm{K}_{2}\left[\mathrm{Ni}\left(\mathrm{L}^{\prime \prime}\right)_{2}\right]$ for complex 2, $\mathrm{L}^{\prime \prime}$ represents $\mathrm{C}_{29} \mathrm{H}_{38} \mathrm{~N}_{4} \mathrm{O}_{4}$ 


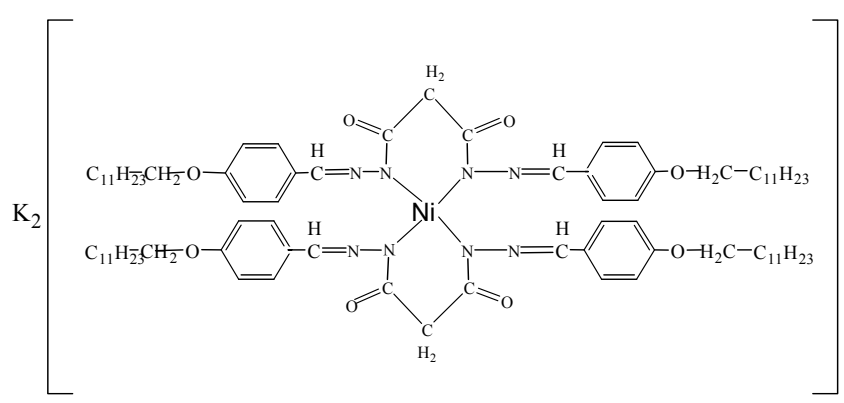

Figure (C). Square planar structure of $\mathrm{K}_{2}\left[\mathrm{Ni}\left(\mathrm{L}^{\prime \prime \prime}\right)_{2}\right]$ for complex 3 , $\mathrm{L}^{\prime \prime \prime}$ represents $\mathrm{C}_{41} \mathrm{H}_{62} \mathrm{~N}_{4} \mathrm{O}_{4}$

Table 5. Analytical data and other physical properties of complexes 1-3

\begin{tabular}{|c|c|c|c|c|c|c|c|}
\hline \multirow{2}{*}{ No } & \multirow{2}{*}{ Complexes } & \multirow{2}{*}{ Colour } & \multirow{2}{*}{$\begin{array}{l}\text { Melting } \\
\text { point }^{\circ} \mathrm{C}\end{array}$} & \multicolumn{2}{|c|}{$\% \mathrm{M}$} & \multirow{2}{*}{$\begin{array}{c}\text { Molar } \\
\text { conductance } \\
\mathrm{Ohm}^{-1} \mathrm{~cm}^{2} \mathrm{~mol}^{-1}\end{array}$} & \multirow{2}{*}{ yield $\%$} \\
\hline & & & & Calculated & Found & & \\
\hline 1 & $\mathrm{~K}_{2}\left[\mathrm{Ni}\left(\mathrm{L}^{\prime}\right)_{2}\right]$ & Yellow & $260(d)$ & 5.00 & 4.6 & 70.29 & 40 \\
\hline 2 & $\mathrm{~K}_{2}\left[\mathrm{Ni}\left(\mathrm{L}^{\prime \prime}\right)_{2}\right]$ & Pale yellow & $250(d)$ & 5.12 & 5.01 & 67.22 & 48 \\
\hline 3 & $\mathrm{~K}_{2}\left[\mathrm{Ni}\left(\mathrm{L}^{\prime \prime \prime}\right)_{2}\right]$ & Greenish yellow & $238(d)$ & 3.95 & 3.89 & 72.69 & 45 \\
\hline
\end{tabular}

Note: Here $\mathrm{d}=$ decomposition temperature.

Table 6. Elemental analysis data of complexes 1-3

\begin{tabular}{ccccccccccc}
\hline & & \multicolumn{2}{c}{$\% \mathrm{C}$} & \multicolumn{2}{c}{$\% \mathrm{H}$} & \multicolumn{2}{c}{$\% \mathrm{~N}$} & \multicolumn{2}{c}{$\% \mathrm{O}$} \\
\cline { 3 - 10 } No & Complexes & & Calculated & Found & Calculated & Found & Calculated & Found & Calculated & Found \\
& & & & & & & & & \\
\hline 1 & $\mathrm{~K}_{2}\left[\mathrm{Ni}\left(\mathrm{L}^{\prime}\right)_{2}\right]$ & 63.43 & 63.02 & 4.46 & 4.25 & 9.54 & 8.98 & 10.91 & 10.45 \\
2 & $\mathrm{~K}_{2}\left[\mathrm{Ni}\left(\mathrm{L}^{\prime \prime}\right)_{2}\right]$ & 60.55 & 59.02 & 6.66 & 6.51 & 9.74 & 9.12 & 11.13 & 10.90 \\
3 & $\mathrm{~K}_{2}\left[\mathrm{Ni}\left(\mathrm{L}^{\prime \prime \prime}\right)_{2}\right]$ & 66.22 & 66.06 & 8.41 & 7.27 & 7.54 & 7.15 & 8.61 & 8.41 \\
\hline
\end{tabular}

Table 7. Magnetic moment data of the complexes $1-3, T=300 \mathrm{~K}$

\begin{tabular}{|c|c|c|c|c|c|c|c|c|c|c|c|}
\hline $\begin{array}{l}\mathrm{N} \\
\mathrm{o}\end{array}$ & $\begin{array}{l}\text { Complexe } \\
\qquad \mathrm{s}\end{array}$ & $\begin{array}{l}\text { Sampl } \\
\mathrm{e} \\
\text { length } \\
\text { ' 'l' in } \\
\mathrm{cm}\end{array}$ & $\begin{array}{l}\text { Weigh } \\
\mathrm{t} \text { of } \\
\text { the } \\
\text { sampl } \\
\mathrm{e} \text { ' } \mathrm{m} \text { ' } \\
\text { in } \mathrm{g}\end{array}$ & $\begin{array}{l}\text { Susceptib } \\
\text { ility of } \\
\text { the empty } \\
\text { tube ' } R_{0} \text { ' }\end{array}$ & $\begin{array}{c}\text { Susceptib } \\
\text { ility of } \\
\text { sample } \\
\text { with } \\
\text { tube' } R \text { ' }\end{array}$ & $\begin{array}{c}\text { Mass } \\
\text { susceptibi } \\
\text { lity, } \chi_{\mathrm{g}} \\
\times 10^{-6} \\
\text { C.G.S } \\
\text { unit }\end{array}$ & $\begin{array}{c}\text { Molecul } \\
\text { ar } \\
\text { weight, } \\
\text { M }\end{array}$ & $\begin{array}{c}\text { Molar } \\
\text { susceptib } \\
\text { ility } \\
\chi_{\mathrm{m}} \times 10^{-3} \\
\text { C.G.S } \\
\text { unit }\end{array}$ & $\begin{array}{c}\text { Diamagn } \\
\text { etic } \\
\text { correctio } \\
\mathrm{n} \chi_{\mathrm{g}} \\
\times 10^{-6} \\
\text { C.G.S } \\
\text { unit }\end{array}$ & $\begin{array}{c}\underset{\mathrm{rr}}{\chi_{\mathrm{rr}}{ }^{\mathrm{co}}} \\
\times 10^{-} \\
3 \\
\text { C.G } \\
. S \\
\text { unit }\end{array}$ & $\begin{array}{c}\mu_{\text {eff }} \\
\text { in } \\
\text { B. } \\
\text { M }\end{array}$ \\
\hline 1 & $\begin{array}{c}\mathrm{K}_{2}\left[\mathrm{Ni}\left(\mathrm{L}^{\prime}\right)\right. \\
2]\end{array}$ & 1.9 & $\begin{array}{c}0.033 \\
1\end{array}$ & -15 & -19 & -0.478 & $\begin{array}{c}1172.89 \\
3\end{array}$ & -0.561 & - & - & Dia \\
\hline 2 & $\begin{array}{c}\mathrm{K}_{2}\left[\mathrm{Ni}\left(\mathrm{L}^{\prime \prime}\right.\right. \\
\left.)_{2}\right]\end{array}$ & 1.7 & 0.04 & -35 & -40 & -0.443 & $\begin{array}{c}1149.50 \\
1\end{array}$ & -0.509 & - & - & Dia \\
\hline 3 & $\begin{array}{c}\mathrm{K}_{2}\left[\mathrm{Ni}\left(\mathrm{L}^{\prime \prime}\right.\right. \\
\left.)_{2}\right]\end{array}$ & 1.6 & $\begin{array}{c}0.042 \\
3\end{array}$ & -21 & -29 & -0.631 & $\begin{array}{c}1485.88 \\
5\end{array}$ & -0.938 & - & - & Dia \\
\hline
\end{tabular}


Table 8. Important infrared spectral bands of complexes 1-3, (as $\mathrm{KBr}$ disc)

\begin{tabular}{cccccc}
\hline No & Complexes & $v(\mathrm{C}=\mathrm{N}) \mathrm{cm}^{-1}$ & $v(\mathrm{C}=\mathrm{C}) \mathrm{cm}^{-1}$ & $v(\mathrm{M}-\mathrm{N}) \mathrm{cm}^{-1}$ & $v(\mathrm{C}=\mathrm{O}) \mathrm{cm}^{-1}$ \\
\hline 1 & $\mathrm{~K}_{2}\left[\mathrm{Ni}\left(\mathrm{L}^{\prime}\right)_{2}\right]$ & 1615 & 1575 & 740 & 1654 \\
2 & $\mathrm{~K}_{2}\left[\mathrm{Ni}\left(\mathrm{L}^{\prime \prime}\right)_{2}\right]$ & 1620 & 1580 & 748 & 1666 \\
3 & $\mathrm{~K}_{2}\left[\mathrm{Ni}\left(\mathrm{L}^{\prime \prime \prime}\right)_{2}\right]$ & 1610 & 1570 & 730 & 1650 \\
\hline
\end{tabular}

Table 9. UV-visible spectrum of complexes 1-3

\begin{tabular}{ccc}
\hline No & Complexes & $\lambda \max (\mathrm{nm})$ \\
\hline 1 & $\mathrm{~K}_{2}\left[\mathrm{Ni}\left(\mathrm{L}^{\prime}\right)_{2}\right]$ & 400 \\
2 & $\mathrm{~K}_{2}\left[\mathrm{Ni}\left(\mathrm{L}^{\prime \prime}\right)_{2}\right]$ & 430 \\
3 & $\mathrm{~K}_{2}\left[\mathrm{Ni}\left(\mathrm{L}^{\prime \prime \prime}\right)_{2}\right]$ & 420 \\
\hline
\end{tabular}

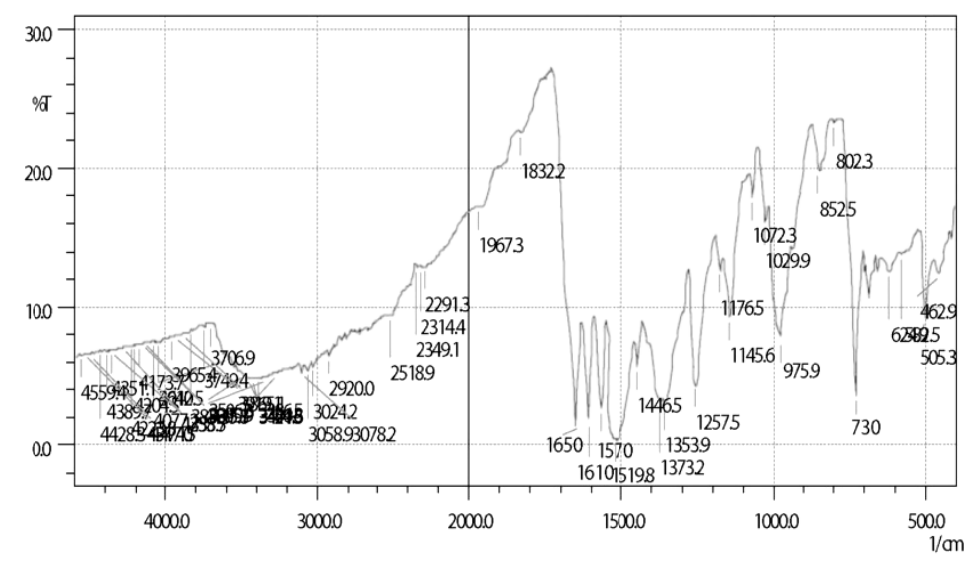

Figure 7. Infrared spectrum of $\mathrm{K}_{2}\left[\mathrm{Ni}\left(\mathrm{C}_{31} \mathrm{H}_{26} \mathrm{~N}_{4} \mathrm{O}_{4}\right)_{2}\right]$ complex 1

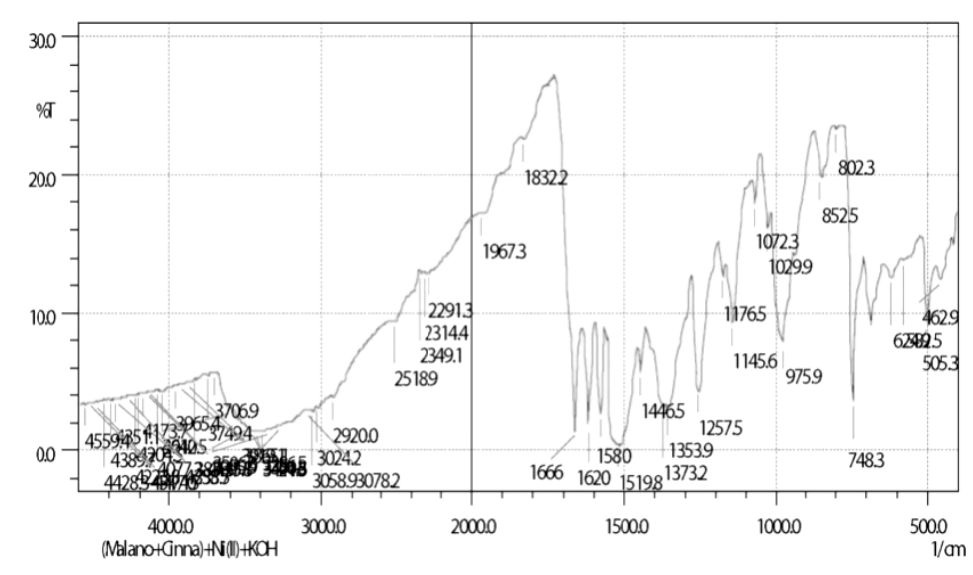

Figure 8. Infrared spectrum of $\mathrm{K}_{2}\left[\mathrm{Ni}\left(\mathrm{C}_{29} \mathrm{H}_{38} \mathrm{~N}_{4} \mathrm{O}_{4}\right)_{2}\right]$ complex 2 


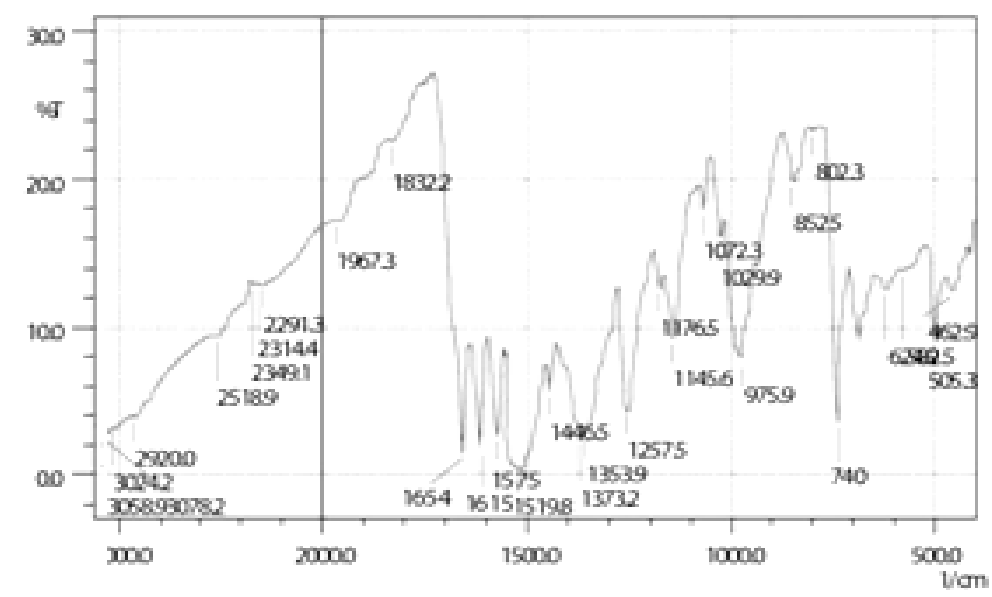

Figure 9. Infrared spectrum of $\mathrm{K}_{2}\left[\mathrm{Ni}\left(\mathrm{C}_{41} \mathrm{H}_{62} \mathrm{~N}_{4} \mathrm{O}_{4}\right)_{2}\right]$ complex 3

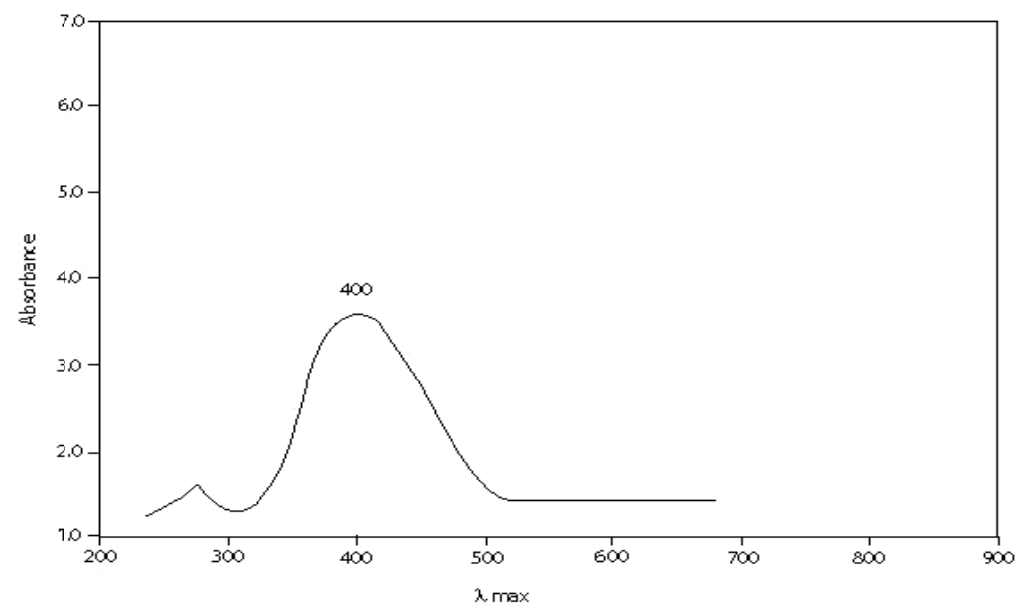

Figure 10. UV-visible spectrum of $\mathrm{K}_{2}\left[\mathrm{Ni}\left(\mathrm{C}_{31} \mathrm{H}_{26} \mathrm{~N}_{4} \mathrm{O}_{4}\right)_{2}\right]$ complex 1

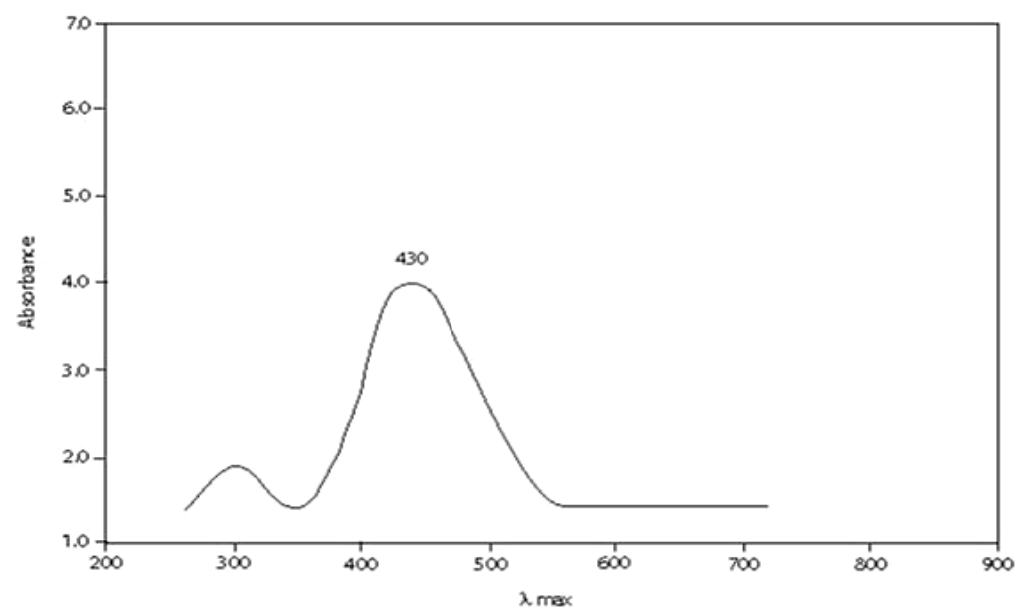

Figure 11. UV-visible spectrum of $\mathrm{K}_{2}\left[\mathrm{Ni}\left(\mathrm{C}_{29} \mathrm{H}_{38} \mathrm{~N}_{4} \mathrm{O}_{4}\right)_{2}\right]$ complex 2 


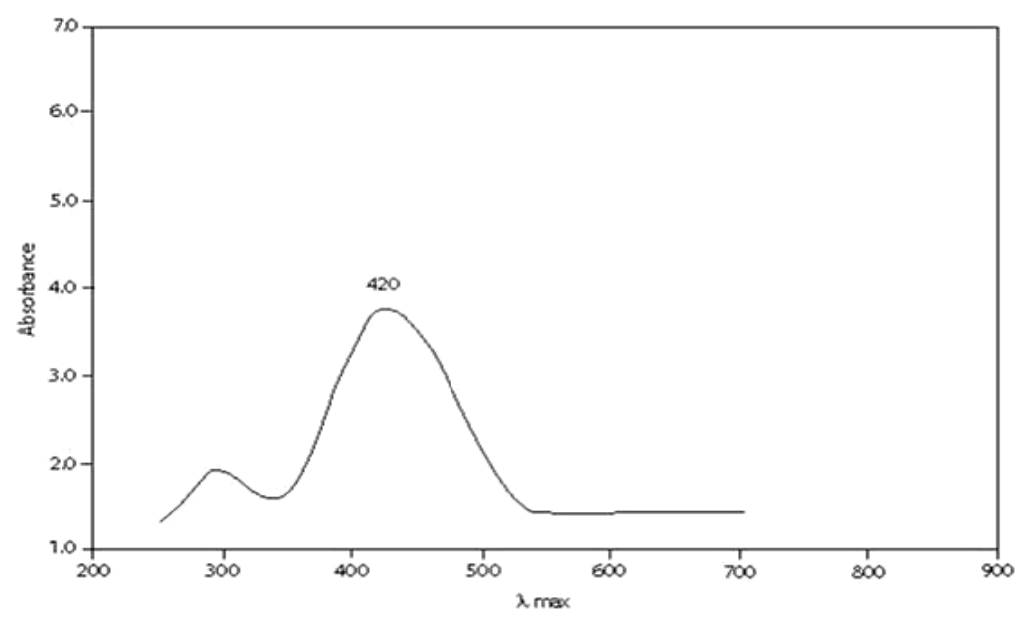

Figure 12. UV-visible spectrum of $\mathrm{K}_{2}\left[\mathrm{Ni}\left(\mathrm{C}_{41} \mathrm{H}_{62} \mathrm{~N}_{4} \mathrm{O}_{4}\right)_{2}\right]$ complex 3

\section{Acknowledgements}

It's a matter of great pleasure of having the opportunity of expression my deepest sense of gratitude, sincere appreciation and heart-felt admiration to my research supervisor Dr. Md. Belayet Hossain Howlader, Professor, Department of Chemistry, University of Rajshahi for his constant guidance, excellent co-operation, continuous encouragement and inspiration accorded to me throughout the entire period of my work.

\section{References}

Basdo, F., \& Johnson, R. (1964). Coordination Chemistry, Benzamine. NY. : W. A. Inc.

Bethe, H. (1929). Tern-Splitting in Crystals. Ann. Phys., 3, 133. http://dx.doi.org/10.1002/andp.19293950202

Figgis, B. N. (1960). Introduction to Ligand Field. New York: John Wiley and Sons, Inc.

Graw, H. B. (1964). Molecular Orbital Theory of Transition Metal Complexes. J. Chem. Educ., 2, 41.

Gruses, F., Fortega, R., March, J. G., \& Cerda, V. (1983). Kinetic-Catalytic Determination of Manganese (II) by Means of Succinimidedioxime. Anal Chem. Acta., $155,299$. http://dx.doi.org/10.1016/S0003-2670(00)85609-3

Lowry, T. M. (1923). The Uniqueness of Hydrogen. J. Ind. Chem. Soc., 42, 316. http://dx.doi.org/10.1002/jctb.5000421303

Orgel, L. E. (1960). An Introduction of Transition Metal Chemistry: Ligand Field Theory. New York: John Wiley and Sons.

Pauling, L. (1960). The Nature of the Chemical Bond (3rd ed.). New York: Cornell University Press, Ithace.

Pouling, L. (1960). Valence Bond Theory in Coordination Chemistry. J. Chem. Educ., 39, 421.

Rossotti, F. J. C., \& Rossotti, H. (1961). The Determination of Stability Constants. Newyork: Mc Graw-Hill.

Sidgwick, N. V. (1923). The Nature of the Link. J. Chem. Soc., 123, 725. http://dx.doi.org/10.1039/ct9232300725

Vanvleck, J. H. (1935). The Group Relation Between the Mulrken and Slater Pauling Theories of Valence. J. Chem. phys., 3, 803. http://dx.doi.org/10.1063/1.1749595

Vanvleck, J. H. (1985). Valence Strength and the Magnetism of Complex Salts. J. Chem. Phys., 3, 807. http://dx.doi.org/10.1063/1.1749596

Werner, A. (1911). New Ideas in Inorganic Chemistry (2nd ed.), translated by E. P. Hedley. London: Longmans, Green \& Co. 